\title{
LIFE HISTORY OF THE FISHFLY, NIGRONIA FASCIATUS (MEGALOPTERA: CORYDALIDAE)
}

\author{
By Donald C. Tarter, ${ }^{1}$ William D. Watkins ${ }^{2}$ \\ and Michael L. Little ${ }^{1}$
}

The objective of this study was to describe certain aspects of the life history of the fishfly, Nigronia fasciatus (Walker), in a small, woodland stream in Cabell County, West Virginia. Some investigators, including Tarter and Watkins (1974), Evans (1972), Neunzig (1966) and Cuyler (1965), have reported taxonomical and distributional information on this fishfly. The egg masses, eggs, and first-instar larvae of $N$. fasciatus were described by Baker and Neunzig (1968), and the mature larva by Cuyler (1965) and Neunzig (1966).

The genus Nigronia Banks I908 includes two recognized species in North America, N. fasciatus (Walker) and N. serricornis (Say). $N$. fasciatus was originally described by Walker (1853) as Chauliodes fasciatus. It has been collected in New York, Pennsylvania, Ohio, Glen Echo, D. C., Maryland, Illinois, Missouri, Arkansas, and Mexico (Davis, I903). In West Virginia, Tarter and Watkins (1974) reported $N$. fasciatus from eight major drainages in 15 counties. The larvae are most often found under rocks and logs in small, woodland streams.

\section{Materials and Methods}

Hisey Fork, a small, woodland stream in Cabell County, West Virginia, is the study area. The stream flows northeast for $7.4 \mathrm{~km}$ and empties into Fourpole Creek near Huntington, West Virginia. The average gradient is $45 \mathrm{~m} / \mathrm{km}$. The stream is about I m wide throughout its length, and the water depth is about $0.1 \mathrm{~m}$. The substrate consists of sand, coarse rubble and large boulders. The riparian woodland is composed of beech Fagus grandifolia Ehrh., yellow poplar Liridendron tulipifera L., oak Quercus spp., and hickory Carya spp.

This study was initiated in September 1972 and continued until August 1973. To study the life history of $N$. fasciatus, the year was

${ }^{1}$ Dept. of Biol. Sci., Marshall Univ. Huntington, W. Va.

${ }^{2}$ Ashland Oil Inc., Res. and Dev. Dept., Catlettsburg, Ky.

Manuscript received by the editor February 16, 1975 
divided into four seasons; fall (Sept.-Nov.), winter (Dec.-Feb.), spring (Mar.-May), and summer (June-Aug.). Usually a single collection was made during the middle month of each season. Larval fishflies were collected from under rocks $(8-50 \mathrm{~cm}$ in diam) and in logs throughout Hisey Fork by handpicking with forceps. Generally, the larvae occurred about I per 20-30 meters of stream length. They were placed in boiling water to prevent shrinkage and stored in 70 per cent ethanol.

Size-frequency distributions of head widths, arranged in $0.2 \mathrm{~mm}$ groups, were employed each season to determine the size classes of $N$. fasciatus larvae. Also, 2 I I larval head widths, measured with a dial vernier caliper (nearest O.I $\mathrm{mm}$ ), were used as an index of growth.

Data regarding larval food habits were determined by foregut analysis. The foreguts were excised and the contents sorted into various taxonomic categories under a dissecting microscope. The number of specimens in each taxon was counted and recorded for each foregut. The following calculations were made seasonally: (I) the percentage of foreguts in which a particular taxon occurred (percentage frequency of occurrence) and (2) the average number of specimens in all foreguts containing that particular taxon.

Fecundity in the adult fishfly $N$. fasciatus was determined by direct counts of ovarian eggs. Both ovaries of Io adults were removed and a total of $68 \mathrm{O} 2$ eggs were counted. The regression of fecundity on total length was calculated and a coefficient of correlation determined.

Water temperature was measured with a thermometer placed near the bottom. Determinations of total alkalinity, total hardness as $\mathrm{CaCO}_{3}$ and $\mathrm{pH}$ were carried out in the laboratory with a Hach chemical kit, Model DR-EL. Dissolved oxygen concentration was measured in the field with a Hach chemical kit, Model AL-36-WR.

\section{Results AND Discussion}

Stream Environment. - During the study period, water temperature ranged from 5.6 to $\mathrm{I} 8.3 \mathrm{C}$, winter and summer, respectively. The average $\mathrm{pH}$ value was 7.7 (range, 7.0-8.0). The waters usually were supersaturated with dissolved oxygen which ranged from 9 to I $3 \mathrm{mg} / \mathrm{l}(\overline{\mathrm{x}}=$ I I $\mathrm{mg} / \mathrm{l})$. Total alkalinity concentrations ranged from 45 to $85 \mathrm{mg} / \mathrm{l}$, winter and summer, respectively $(\overline{\mathrm{x}}=68$ $\mathrm{mg} / \mathrm{l})$. The average total hardness concentration was $\mathrm{I} 63 \mathrm{mg} / \mathrm{l}$; the range was $\mathrm{I} 2 \mathrm{O}$ (spring) to $2 \mathrm{IO}$ (summer) $\mathrm{mg} / \mathrm{l}$. 
$7.0-$

(80)

(59)

(25)

(47)

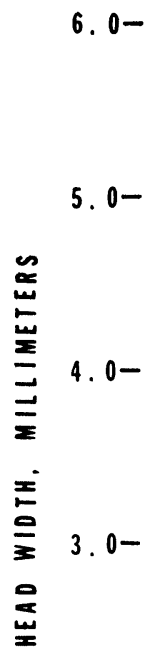

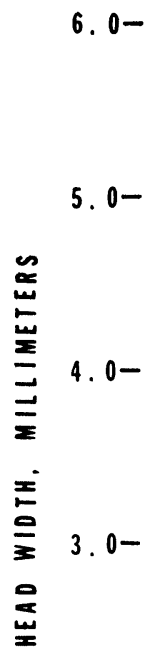

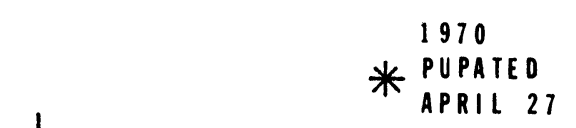

2. $0-$

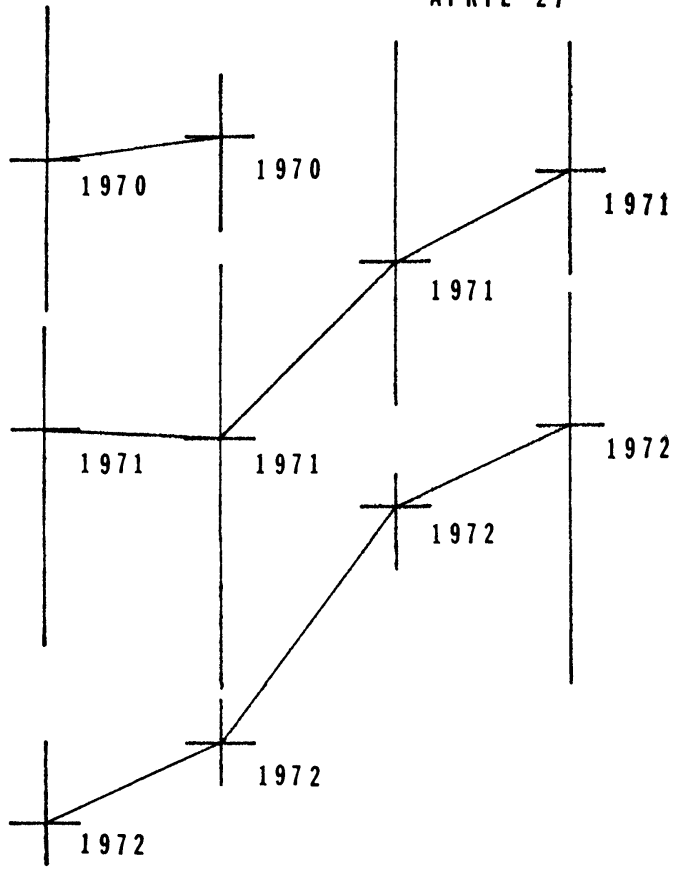

$1.0-$

$0.0-$

$\begin{array}{cccc}\text { I } & \text { I } & \text { I } & \text { I } \\ \text { FALL } & \text { WINTER } & \text { SPRING } & \text { SUMMER } \\ 1972 & 1973 & 1973 & 1973\end{array}$

Figure 1. Seasonal size-frequencies of $N$. fasciatus larvae from Hisey Fork, Cabell Co., W. Va. Number of larvae is given in parentheses, and size classes are marked with year of hatching. 
Larval Food Habits. - The following food categories were identified in the foreguts of larval fishflies from Hisey Fork: Isopoda, Diptera, Ephemeroptera, Megaloptera, and Trichoptera. Of the I8I foreguts examined, I70 (93.9\%) contained food and II $(6.1 \%)$ were empty. The highest percentage of empty foreguts $(8.9 \%)$ occurred in fall.

Of the identifiable food materials, the isopod Asellus militaris (Hay) ranked first in percentage frequency of occurrence in all seasons. It ranged from 22.9 per cent in summer to 56.0 per cent in spring. The largest number (27) and the highest average (1.2) of isopods occurred in fall.

Larvae of the caddisfly Cheumatopsyche sp. ranked second to isopods in percentage frequency of occurrence in summer (14.3), fall (19.7) and winter (18.0). Pupation and emergence could be responsible for their lowest frequency $(8.0 \%)$ in spring. In fall, the highest average (I.I) and greatest number (I5) of larval caddisflies occurred in the diet of the fishfly.

A limited number of mayfly naiads, Ephemerella coxalis McDunnough, entered the diet in the spring and summer. The naiads ranked second $(20.0 \%)$ to isopods in percentage frequency of occurrence in spring.

Chironomid larvae were consumed in winter, where they occurred with a frequency of 10.3 per cent. They ranked behind isopods and caddisflies as a food source for larval fishflies.

Some cannibalism was found in all seasons. It reached the highest frequency of occurrence ( $1 \mathrm{I} .4 \%$ ) in summer, where four $N$. fasciatus larvae were consumed.

Digested and unidentified materials comprised a high percentage frequency of occurrence in fall (55.0), winter (46.I) and summer (5I.4). In spring, they were found in 24 per cent of the foreguts.

Minshall (1967) reported that larvae of $N$. fasciatus from Morgan's Creek, a woodland springbrook in Meade County, Kentucky, consumed Gammarus, Asellus, Ectopria and unidentified amorphous materials. The guts of most larvae were partially full, and the consumed material was of indeterminate nature.

Larval Development. - The larval population of $N$. fasciatus consisted of three size classes (Fig. I). In the youngest size class (1973, year of hatching), laboratory hatched larvae in June measured $0.75 \mathrm{~mm}$ in head width (Fig. 2 and Table I). The smallest larva in the stream measured $\mathrm{I} .3 \mathrm{~mm}$ in head width and was collected in fall (29 November 1972). The method of collection precluded getting large numbers of the youngest size class from the 
Table 1. Seasonal head widths (mm) of larval size classes of $N$. fasciatus, Hisey Fork, Cabell Co., W. Va.

\begin{tabular}{|c|c|c|c|c|}
\hline $\begin{array}{c}\text { Size } \\
\text { Classes } \\
\text { (Year of } \\
\text { Hatching) }\end{array}$ & Fall & Winter & Spring & Summer \\
\hline 1970 & $\begin{array}{l}\bar{x}=5.3 \\
(4.5-6.2) \\
N=41\end{array}$ & $\begin{array}{l}\bar{x}=5.5 \\
(4.9-5.8) \\
N=27\end{array}$ & PUPATED & \\
\hline 1971 & $\begin{array}{l}\overline{\mathrm{x}}=3.8 \\
(2.5-4.4) \\
\mathrm{N}=35\end{array}$ & $\begin{array}{l}\overline{\mathrm{x}}=3.7 \\
(2.5-4.7) \\
\mathrm{N}=30\end{array}$ & $\begin{array}{l}\bar{x}=4.7 \\
(3.9-6.0) \\
N=20\end{array}$ & $\begin{array}{l}\bar{x}=5.3 \\
(4.7-6.0) \\
N=22\end{array}$ \\
\hline 1972 & $\begin{array}{l}\bar{x}=1.5 \\
(1.3-2.0) \\
N=4\end{array}$ & $\begin{array}{l}\bar{x}=2.0 \\
(1.7-2.2) \\
N=2\end{array}$ & $\begin{array}{l}\bar{x}=3.3 \\
(3.0-3.5) \\
N=5\end{array}$ & $\begin{array}{l}\bar{x}=3.8 \\
(2.3-4.6) \\
N=15\end{array}$ \\
\hline 1973 & & & & $\begin{array}{c}\bar{x}=0.8 \\
(0.8) \\
N=10\end{array}$ \\
\hline
\end{tabular}

stream. The mean head width of larvae at the end of the first year of development (1972) was $3.8 \mathrm{~mm}$ (Table $\mathrm{I}$ and Fig. 2). After the 2nd year of development (I97I), the mean head width was $5.3 \mathrm{~mm}$ (Table I and Fig. 2). At the end of the 3 rd year ( 1970 ), just prior to pupation, the mean head width was $5.5 \mathrm{~mm}$ (Table I and Fig. 2).

Larval head width demonstrated seasonal changes in growth (Fig. 2). The greatest growth rate $(69.7 \%)$ of the larval population, occurred from winter to spring in the 1972 size classes. This development coincided with the greatest seasonal changes in water temperature, 5.6 $\mathrm{C}$ and $\mathrm{x} 6.0 \mathrm{C}$, winter and spring, respectively.

Pupal Stage. - One pupa was collected in the spring (April 27). It was found under a flat rock (ca $45 \mathrm{~cm}$ in diam) in an earthen cell $30 \mathrm{~cm}$ from the stream. Based on field observations of the first adult, pupation lasted approximately $2 \mathrm{I}$ days.

Neunzig (1966) reported that $N$. fasciatus, in Nature Trail Creek, North Carolina, started pupation around May 5 and reached a peak the following week. The pupae were located under moss in earthen cells about 6-12 inches from the creek. Minshall (1968) noted that $N$. fasciatus from Morgan's Creek, Kentucky, pupated in the early spring (April). 

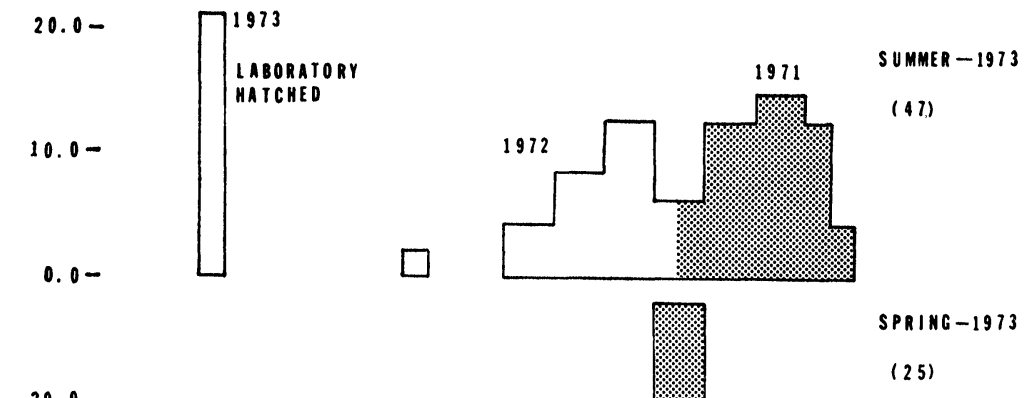

$20.0-$
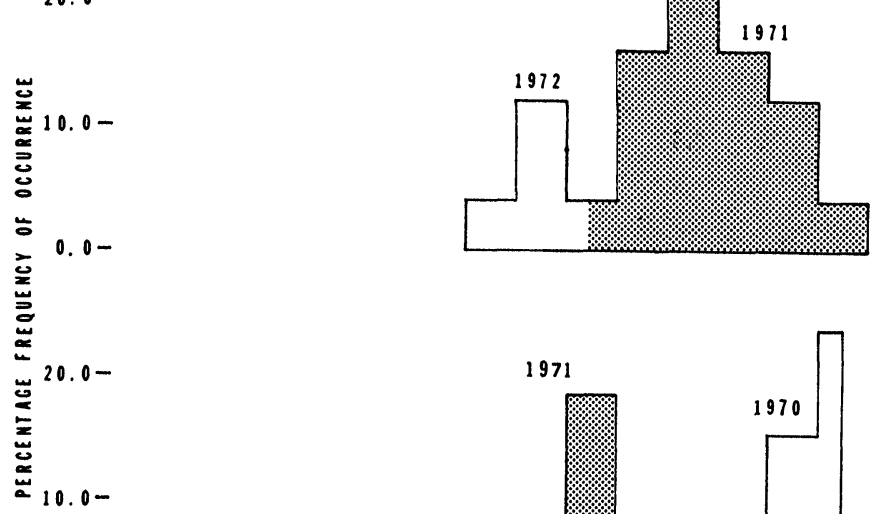

$0.0-$

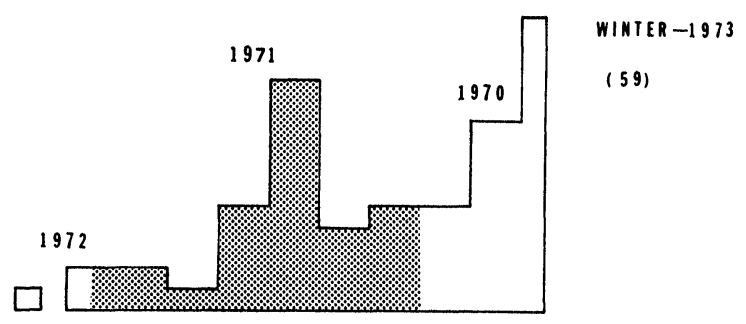

$10.0-$

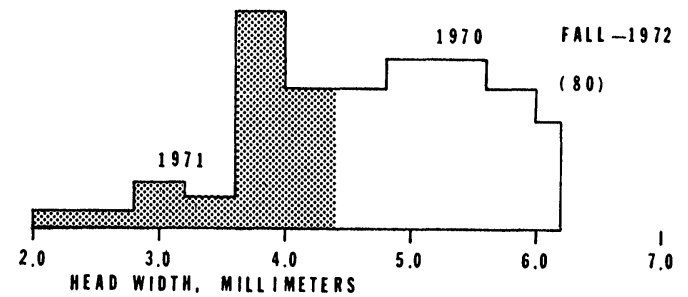

Figure 2. Seasonal variation of the head width in $N$. fasciatus larvae in Hisey Fork, Cabell Co., W. Va. Vertical lines = ranges, horizontal lines $=$ means. 
Adult Stage. - The first adult fishfly was collected near the stream on May i6. In one hour 13, 8 and 3 adults were observed on May 20, 22, and 25, respectively. On different occasions, several wings of adult fishflies were found scattered along the stream bank. Apparently, birds or other predators had fed upon the adults. No wings or fishflies were found after May 25. The approximate flying season for $N$. fasciatus was Io days.

Oviposition was observed in the field on May 20 and 22. Females oviposited their entire egg mass on the underside of leaves 4-6 m above the stream between 1300 and 1600 hours. Several leaves with egg masses were brought to the laboratory and suspended over water. Hatching occurred in I4 days and first-instar larvae ( $1.5-2.0 \mathrm{~mm}$, body length) fell into the water and crawled underneath rocks.

There was high correlation $(r=0.95)$ between the numbers of eggs produced and the total length of female fishflies. The following equation was calculated to express this relationship.

$$
\begin{aligned}
\mathrm{Y} & =-2800.0+93.9 \mathrm{X} \\
\text { where } \mathrm{Y} & =\text { the number of eggs, and } \\
\mathrm{X} & =\text { total length, mm }
\end{aligned}
$$

Ovarian egg counts of ro females showed a range from 275 to II 34 eggs per female $(\bar{x}=680)$.

\section{Acknowledgements}

We are grateful to the following graduate students for assistance in the field: Diana Ashley, Randy Farmer, Jerry Faulkner, David Hamilton, Nell Hanson, Fred Kirchner, Michael Midkiff, Sam Much, Steve Muth and Douglas Steele. Special thanks to Dr. N. H. Anderson, Department of Entomology, Oregon State University, for critically reading the manuscript and Judy Tarter for typing the manuscript.

\section{References Cited}

Baker, J. R., AND H. H. Neunzig.

1968. The egg masses, eggs, and first-instar larvae of eastern North American Corydalidae. Ann. Entomol. Soc. Am. 61: 1181-1187.

BANKs, N.

1908. On the classification of the Corydalinae with description of a new species. Proc. Entomol. Soc.. Wash. 10: 27-30.

CUYler, R. D.

1965. The larvae of Nigronia fasciatus Walker (Megaloptera: Corydalidae). Entomol. News 76: 192-195. 
Davis, K. C.

1903. Sialididae of North and South America. In Aquatic insects in New York State. N. Y. State Mus. Bull. 68: 442-487, pl. 51, 52.

Evans, E. D.

1972. A study of the Megaloptera of the Pacific Coastal region of the United States. Ph.D. Dissertation, Oregon State University, Corvallis, Oregon.

Minshall, G. W.

1967. Role of allochthonous detritus in the trophic structure of a woodland springbrook community. Ecol. 48 : 139-149.

1968. Community dynamics of the benthic fauna in a woodland springbrook. Hydrobiol. 32 : 305-339.

Neunzig, H. H.

1966. Larvae of the genus Nigronia Banks (Neuroptera: Corydalidae). Proc. Entomol. Soc. Wash. 68 : 11-16.

TARTer, D. C., AND W. D. Watkins.

1974. Distribution of the fishfly genera Chauliodes Latreille and $\mathrm{Ni}$ gronia Banks in West Virginia (Megaloptera: Coryalidae).

WALKER, R. Proc. W. Va. Acad. Sci. (In press.)

1853. List of the specimens of neuropterous insects in the collection of the British Museum. London. Part II; 193-476. 

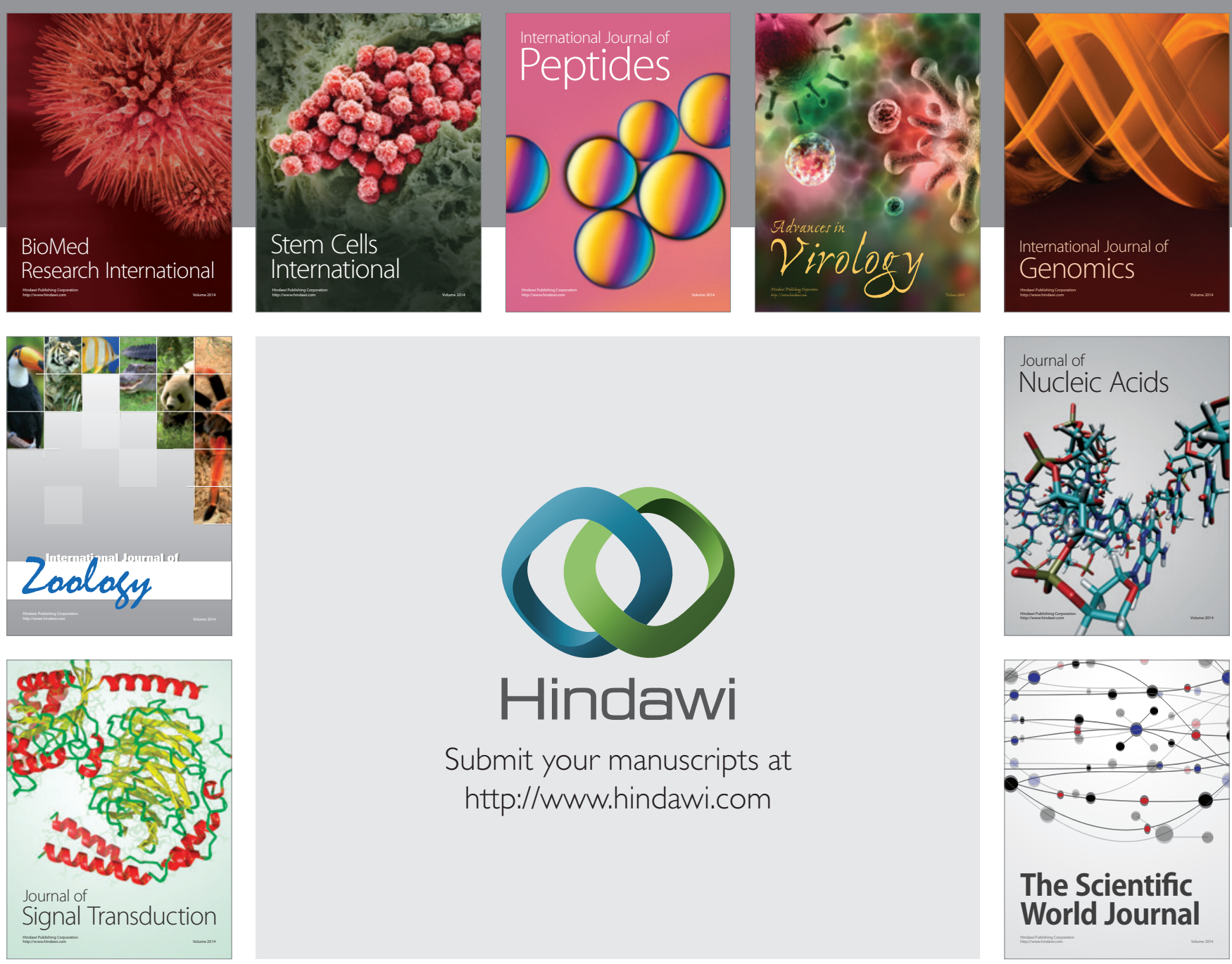

Submit your manuscripts at

http://www.hindawi.com
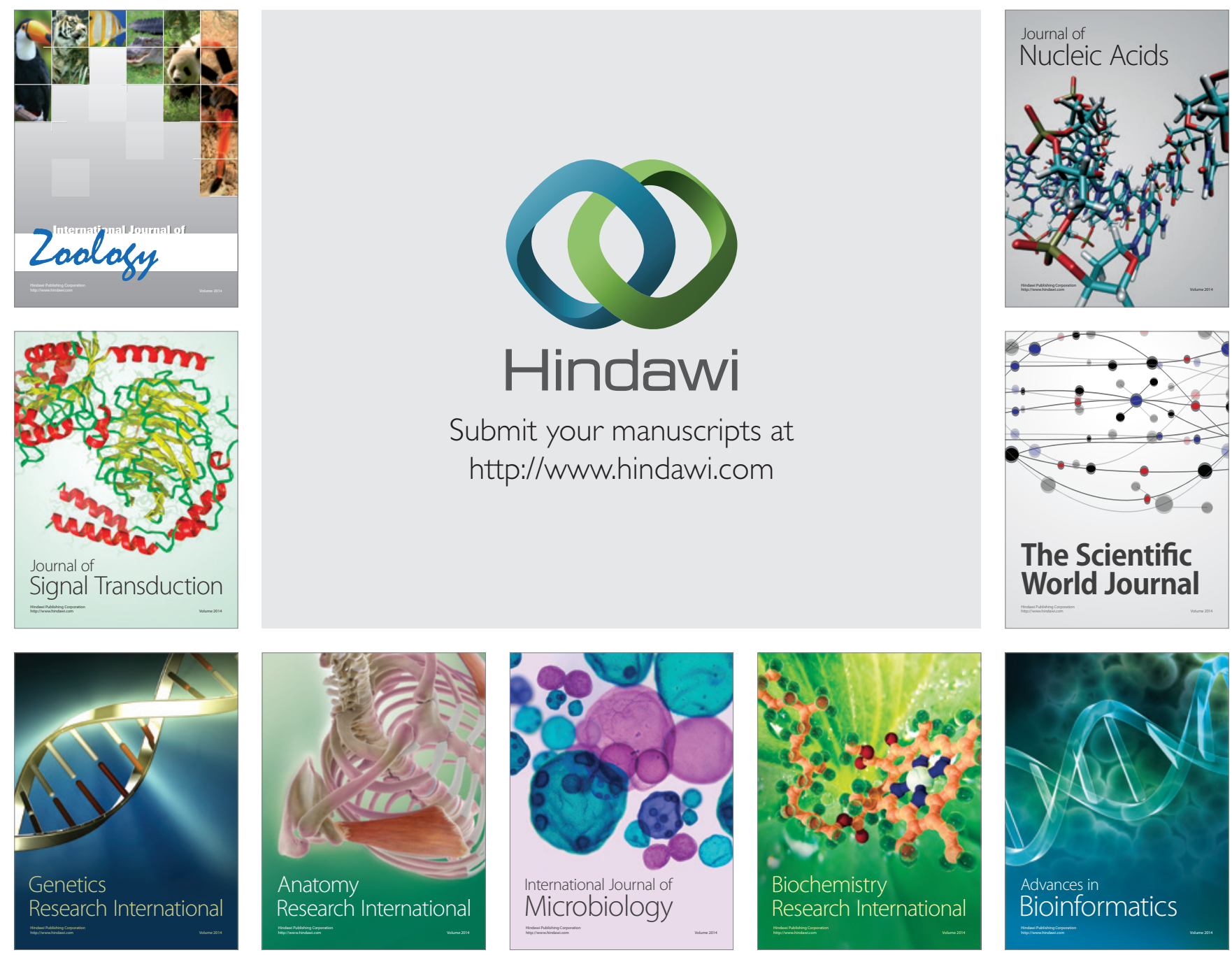

The Scientific World Journal
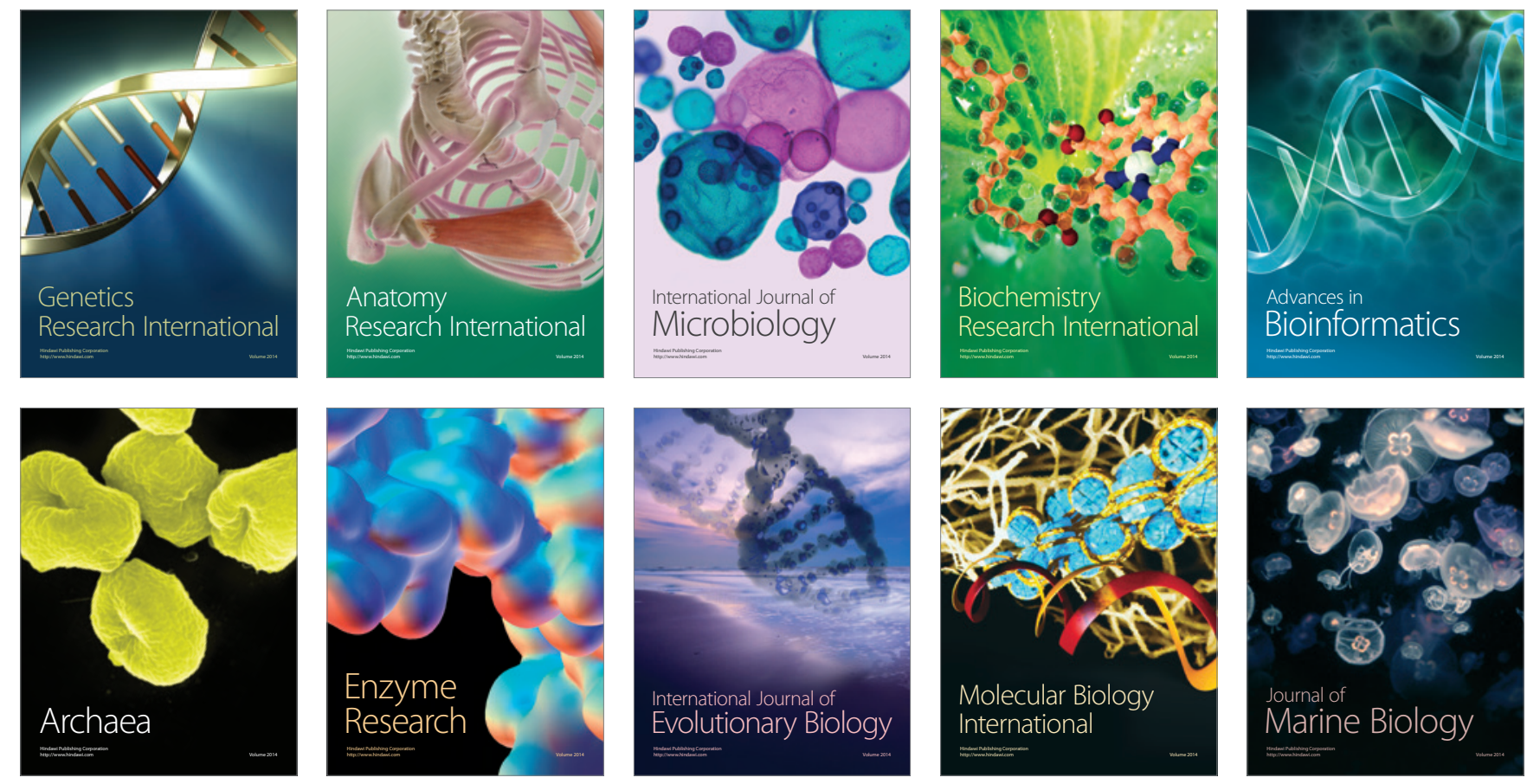